\title{
G5. MONITORAMENTO RÁPIDO DE COBERTURAS VACINAIS (MRC): UMA ESTRATÉGIA DE SUPERVISÃO E INTERVENÇÃO NO ESTADO DO CEARÁ.
}

Elaine Cristina da Silva Alves Bastos ${ }^{1}$; Ana Débora Assis Moura ${ }^{1}$; Ana Karine Borges Carneiro; Ana Vilma Leite Braga ${ }^{1}$; Maria Júlia Araújo Borges ${ }^{1}$; Surama Valena Elarrat Canto ${ }^{1}$; Teresa Wilma Silva Figueiredo ${ }^{1}$.

${ }^{1}$ Secretaria da Saúde do Estado do Ceará.

INTRODUÇÃo O monitoramento rápido de coberturas vacinais (MRC) é uma estratégia de rotina utilizada em diversos países das Américas, de acordo com a recomendação da Organização Pan-Americana de Saúde (OPAS). É um método útil para a avaliação da situação vacinal local, e seus resultados devem ser utilizados para redefinir as ações de vacinação, contribuindo para a melhoria das coberturas vacinais e sua homogeneidade.

OBJETIVO Descrever os motivos de não vacinação das crianças no MRC da vacinação contra sarampo, no ano 2015, informado pelas mães.

METODOLOGIA Estudo do tipo descritivo, em que foram analisadas 52.216 cadernetas de vacinação de crianças na faixa etária de 6 meses a menores de 5 anos de idade, residentes no estado do Ceará. O MRC da vacina contra sarampo (tríplice e tetra viral) ocorreu no ano de 2015, após a campanha nacional de vacinação contra sarampo e poliomielite, realizada em 2014. A coleta de dados ocorreu no primeiro semestre de 2015, através do sistema de informação do Programa Nacional de Imunizações (SI-PNI).

RESULTADOS Verificou-se um número de 836 crianças não vacinadas contra sarampo. Para cada criança poderia ser elencado mais de um motivo de não vacinação. Portanto, os motivos foram num total de 1.388 (100\%), dentre eles: $2(0,1 \%)$ evento adverso em dose anterior; $6(0,4 \%)$ contra indicação médica; 7 (0,5\%) posto de vacinação fechado; 13 (1\%) recusa da vacina; $16(1,2 \%)$ perdeu/sem comprovante vacinal; $24(1,7 \%)$ várias injeções ao mesmo tempo; $36(2,6 \%)$ dificuldade de ir ao posto de vacinação (acesso); 110 (7,9\%) não estava agendada; 135 (9,7\%) faltou vacina; 219 $(15,8 \%)$ falta de tempo; $820(59,1 \%)$ outros motivos. Percebeu-se um grande número 
de crianças não vacinadas no estado do Ceará, ocasionando um bolsão de susceptíveis. Os motivos foram bem variados, podendo-se destacar a dificuldade de acesso dos usuários aos locais de vacinação; falhas relacionadas à gestão das salas de vacinação, como a falta de agendamento da vacina, que é fundamental para a orientação dos responsáveis, a garantia do estoque do imunobiológico, já que o mesmo não passou por nenhum momento de desabastecimento no país, bem como a falta de flexibilidade nos horários de funcionamento das Unidades de Saúde. Observou-se um número considerável de outros motivos, não sendo possível descrevê-los, já que a fonte de dados não fornece essa informação, tornando-se um fator dificultador de análise desses dados.

CONCLUSÃO Sugere-se correção dessa falha em futuros monitoramentos, e que a análise desses dados possa ser realizada por cada Unidade Básica de Saúde, para que sejam implementadas intervenções no sentido de minimizar os fatores contribuintes para a não vacinação das crianças no estado do Ceará.

PALAVRAS-CHAVE monitoramento, coberturas vacinais, imunobiológico. 